\title{
Para uma reinterpretação da morte como consequência do pecado original
}

\author{
For a reinterpretation of death \\ as a consequence of original sin
}

Renato Alves de Oliveira

\section{Resumo}

Este artigo propõe uma nova hermenêutica da relação entre o pecado original e a morte. Para a reflexão bíblica (Gn 2-3; Rm 5,12) e a tradição cristã, a morte física teria entrado no mundo como fruto do pecado de Adão. A vida física teria passado de imortal à mortal, em razão do pecado. Esta visão clássica, que perdurou até os inícios do século XX, padece de um fisicismo na compreensão do pecado original, da morte, da vida e da imortalidade paradisíaca. A visão fisicista desses conceitos é reinterpretada à luz de uma percepção evolutiva do mundo, de uma reflexão bíblico-teológica mais ampliada sobre o conceito de morte, das contribuições antropológicas da filosofia contemporânea sobre a morte e de um horizonte mais existencial na abordagem desses conceitos. Dentro de uma nova interpretação, a morte seria consequência do pecado em virtude da forma que se experimenta o morrer como momento de angústia, de solidão e de sofrimento. $\mathrm{O}$ foco não estaria na morte física, mas no modo como se experimenta o morrer.

Palavras-chave: Pecado original. Morte. Vida. Imortalidade. Reinterpretação.

\section{Abstract}

This article proposes a new hermeneutic of the relationship between original sin and death. For biblical reflection (Gen 2-3; Rom 5:12) and the 
Christian tradition, physical death would have entered in the world as the fruit of Adam's sin. Physical life would have passed from immortal to mortal, because of sin. This classic vision, which lasted until the beginning of the 20th century, suffers from a physicalism in the understanding of original sin, death, life and paradisiacal immortality. The physicist view of these notions is reinterpreted in the light of an evolutionary perception of the world, of a more biblical-theological reflection on the concept of death, of the anthropological contributions of contemporary philosophy on death, and of a more existential horizon in approaching these concepts. Within a new interpretation, death would be a consequence of sin by the form in which death is experienced as a moment of anguish, loneliness, and suffering. The focus would not be on physical death, but on the way one experiences dying.

Keywords: Original Sin. Death. Life. Immortality. Reinterpretation.

\section{Introdução}

O que é o pecado original? O que é a morte? Há um nexo causal entre o pecado e a morte? No âmbito bíblico, a morte tem uma gama de significados. No entanto, o significado que se impôs, historicamente, a partir da leitura de $\mathrm{Rm} 5,12$, foi da morte física como fruto do pecado original. A morte teria entrado no mundo em relação direta com a culpa. Esta leitura foi absorvida pela teologia clássica e pelo magistério da Igreja Católica. Trata-se de uma visão fisicista que perpassa as noções do pecado original, da morte, da imortalidade paradisíaca e da vida. O pecado original, que consiste no pecado cometido por Adão, seria visto como uma autoafirmação e um ato de rebeldia da liberdade humana que teria agido prescindindo da vontade de Deus. Esse pecado, que teria ocasionado a entrada da morte física no mundo, seria transmitido dos pais para os filhos. Neste caso, se Adão, hipoteticamente, não tivesse pecado estaria isento da morte física. Assim, o pecado de Adão teria mudado a constituição da vida física que passou de imortal à mortal. Esta visão predominou até $\mathrm{O}$ final do século XIX e os inícios do século XX.

A partir das contribuições da filosofia contemporânea, particularmente do existencialismo (M. Heidegger, J. P. Sartre, L. Lavelle, G. Marcel e outros), a morte passou por um processo de humanização. Estas contribuições tiveram um impacto na teologia contemporânea, possibilitando uma reinterpretação da 
morte. Historicamente, a morte não foi objeto de uma verdadeira investigação teológica. A teologia clássica não se ocupou da morte em si mesma, como fenômeno humano, mas com o que se ocultava atrás dela. Ou seja, a teologia clássica se preocupou mais com a vida pós-mortal do que com a morte. É com a teologia contemporânea que a morte se tornou, em e por si mesma, objeto de investigação teológica. Isso proporcionou uma reinterpretação das noções da morte, da vida, do pecado e da imortalidade paradisíaca. Essas noções são reinterpretadas num sentido mais existencial e humano.

\section{Fundamentos bíblicos sobre a morte como consequência do pecado original}

No âmbito bíblico, a morte não goza de uma compreensão unificada. Basicamente, a morte está ligada à condição frágil e provisória da criatura e à ruptura da comunhão com Deus, instaurada pelo pecado. Em outros termos, a morte, na visão bíblica, tem um aspecto natural e espiritual.

No horizonte do Antigo Testamento (AT), a vida e a morte não são realidades abstratas, mas concretas e opostas. A concepção da morte é determinada pela visão que se tem da vida, a qual é concebida como um dom divino. É Deus quem chama o ser humano à existência, concedendolhe o hálito de vida, a ruah (Ecl 12,1-7). O começo do tempo de sua vida é fixado por Deus que lhe concede o sopro da vida. Deus pode retirar o seu hálito, segundo seu desígnio, decretando a morte do ser humano que retorna à sua originária condição de pó $(\mathrm{Ecl} 12,7)$. Para a antropologia hebraica, o ser humano é uma unidade plural (basar, nefesh e ruah), logo a morte consiste na cessação de toda atividade vital. No entanto, a morte não é a aniquilação total do ser humano, porque uma dimensão sombria e precária de sua existência ontológica, denominada de refaim, permanece depois da morte no sheol, o lugar subterrâneo de trevas e escuridão (Jó 10,21-22) para o qual descem todos os seres humanos. No sheol, não há espaço para a glorificação e o louvor a Deus (Is 38,18-19). A morte representa a ausência de comunicação, de movimento e de relação. A morte, o morto e a representação do mundo dos mortos simbolizam a impureza. ${ }^{1}$

A morte é um fato natural impresso na condição de todos os viventes. Trata-se de uma realidade dada e inerente à existência de todos os viventes.

${ }^{1}$ WOLFF, H.W., Antropologia do Antigo Testamento, p. 137-160. 
Deste modo, o homem religioso do AT está diante da irrevogabilidade da morte com um espírito perfeitamente resignado. A morte é a lei universal de toda carne (Eclo 41,4; Sb 7,1) e o denominador comum entre todos os viventes. A universalidade da morte abrange os seres humanos e os animais (Ecl 3,18-20). No AT, esta lei geral da existência é descrita de diversas formas: serena, no caso de uma velhice vivida de um modo feliz (Gn 15,15; 25,8); como conclusão de uma vida sem esperança (Ecl 4,2-3); em forma de um anjo exterminador (Ex 12,23; 2Sm 24,16; 2Rs 19,35); como um evento prematuro (Jó 20,11) e como enfermidade que representa um estado de morte $(\mathrm{Sl} \mathrm{88,4).} \mathrm{Estas} \mathrm{descrições} \mathrm{têm}$ um denominador comum: a morte é o caminho de toda a terra (1Rs 2,2). ${ }^{2}$

Um momento importante acerca do desenvolvimento do pensamento hebraico sobre a morte é assinalado pela teologia mosaica. A organização social e jurídica de Israel, mediante o código da aliança e da santidade, possibilitou o surgimento de muitos artigos de lei que culminam na pena de morte. A morte é vista como infidelidade a um pacto e violação à aliança (Is 24,5-6). Há uma relação entre a lei e a morte. Trata-se de uma pena em razão de uma infração cometida. A morte é pena imposta em consequência do burlamento de uma norma. Assim, a ideia da morte passa por uma evolução: de um evento natural que acomete todo ser vivo a um fato jurídico-penal. A morte consiste na aplicação da justiça em razão do castigo cometido pela transgressão da lei.

O ser humano é criado em vista da aliança com Deus. Ou seja, a vida tem um fundamento religioso. Neste contexto, a ideia da morte consiste numa ruptura e numa desconexão na comunhão com Deus e com os outros. É o pecado que introduz o ser humano nesta situação letal de fratura. O pecado é a quebra na aliança com Deus e o fechamento em si mesmo. É o ser humano que, através do pecado, livremente diz "não" para Deus, experimentando um estado de separação dele e dos outros. O livre distanciamento de Deus faz com que o ser humano viva "com a morte, na morte e em uma morte eterna". ${ }^{3} \mathrm{O}$ pecado introduz o ser humano num estado de morte. Neste contexto, a morte do ser humano transcende sua dimensão física e natural, relacionada com a sua condição corruptível e frágil, assumindo uma configuração moral e espiritual. A morte, como sinal visível do obscuro destino que domina o ser humano, deriva da situação religiosa que ele assumiu na relação com Deus.

\footnotetext{
${ }^{2}$ MACKENZIE, J. L., Morte, p. 633.

${ }^{3}$ CIMOSA, M., Morte-risurrezione nella Bibbia, p. 76.
} 
O pecado é um ato livre e voluntário de rejeição, ruptura e desobediência na comunhão do ser humano com Deus. Esta fratura na aliança com Deus tem como consequência a morte. Na visão da interpretação clássica sobre Gn 2-3, pautada numa leitura etiológica, historicista e realista, Adão, a criatura corporativa e original, foi criado para viver na comunhão plena com Deus, o que lhe garantiria a imortalidade paradisíaca. No entanto, por um ato desobediente, Adão comeu do fruto da árvore do conhecimento e rompeu a comunhão com Deus, precipitando no pecado e introduzindo a morte no mundo. Por dom de Deus, Adão estaria destinado à imortalidade de todo o seu ser. Todavia, por causa do pecado, Adão teria passado da condição de imortal à mortal. Adão é visto como uma figura corporativa, logo, introduzindo a morte no mundo, ele teria tornado todo o gênero humano sujeito à condição mortal. Doravante, a morte se tornaria uma realidade onipresente para todo ser humano. Assim, a morte teria entrado no mundo em estreita conexão com a culpa. Desobedecendo, Adão teria escolhido viver sob o reinado da morte. Assim, devido a um fato de ordem moral e espiritual, a condição humana teria conhecido a condenação à morte. Seria a dimensão física da morte, enquanto decesso material e diluição corpórea, que seria pena de pecado.

Na visão da interpretação contemporânea de Gn $2-3,{ }^{4}$ não seria possível afirmar que a morte teria entrado no mundo pela via do pecado de Adão. No relato, Deus ameaça com castigo de morte quem comesse do fruto da árvore do conhecimento. No entanto, o fruto é comido pelo casal das origens e o castigo não é executado. O castigo é transformado na imposição de uma vida cheia de percalços (Gn 3,16-19) e na expulsão do jardim do Éden (Gn 3,23). O eufemismo usado para falar da morte, em Gn 3,19 ("tu és pó e ao pó tornarás"), não a conecta diretamente com o pecado, mas com a condição criatural do ser humano. A morte não é vista como a imposição de um castigo em razão de uma transgressão, mas um evento que pertence à condição natural do ser humano. Aquele que foi modelado com o pó da terra $(\mathrm{Gn} 2,7)$ retornará à sua condição de pó, no final de sua existência. $O$ texto não apresentaria um nexo causal entre o primeiro pecado e a morte e nem entre o primeiro pecado e a situação universal de pecado. ${ }^{5}$ Apesar de alguns exegetas contemporâneos

${ }^{4}$ Os autores protestantes (teólogos sistemáticos e exegetas) se inclinam para uma leitura mais
simbólica desse texto de Gn. Já os autores católicos (teólogos sistemáticos e exegetas) se
inclinam para uma interpretação de caráter mais etiológica, porém sem negar a índole simbólica
do texto (RUIZ DE LA PEÑA, J. L., El don de Dios, p. 68-76).
${ }^{5}$ WOLFF, H. W., Antropologia do Antigo Testamento, p. 157; WESTERMANN, C., Funda- 
refutarem a conexão causal entre a morte e o pecado das origens (Gn 2-3), alguns textos bíblicos do AT, baseados nesse texto de $\mathrm{Gn}$, associam o pecado à morte (Sb 2,23-24; Eclo 25,24).

O que foi vislumbrado pelo AT torna-se evidente no Novo Testamento (NT): a relação entre a morte e a culpa. No NT, o tema da morte como consequência do pecado é tratado principalmente por Paulo ( $\mathrm{Rm} 5,12-21$; 6,23 ; 1Cor 15,21). Na visão paulina, a morte está relacionada com o pecado, a lei, a carne e o batismo. Um dos textos capitais sobre a relação entre a morte e o pecado é o de Rm 5,12: "Eis porque, como por meio de um só homem o pecado entrou no mundo e, pelo pecado, a morte, assim a morte passou a todos os homens porque todos pecaram". A expressão "um só homem" é atribuída a Adão, que seria o protagonista da entrada do pecado e da morte no mundo. As categorias "pecado" e "morte" remetem a uma experiência de ruptura e de separação. O pecado é visto como uma ruptura na comunhão com Deus, com outros e com o próprio pecador. A experiência do pecado já seria uma experiência de morte espiritual e social. Já a morte, no sentido antropológico, seria uma experiência de ruptura com esta condição de vida terrena. A morte é vista como o fim da condição histórica, biológica e existencial do ser humano. No sentido teológico, "a morte surge como uma espécie de símbolo do escuro destino que corrompeu e afetou na raiz a relação do homem com Deus". ${ }^{6}$ A morte irromperia como sinal da "corrupção escatológica" e do "afastamento de Deus". ${ }^{7}$

Como o ato de Adão pode introduzir a morte no mundo, tornando o gênero humano mortal? $\mathrm{O}$ fato de Adão ser uma figura representativa do gênero humano, ou seja, de constituir uma personalidade corporativa, faz com que toda ação tenha uma dimensão coletiva. Deste modo, todo o gênero humano estaria contemplado no pecado de Adão, que significou "o início absoluto da experiência do mal na humanidade. Este início situa-se no momento em que começou a história humana: a provação da liberdade e o pecado que lhe seguiu foram o primeiro acontecimento determinante para todos os outros". ${ }^{8}$ $\mathrm{O}$ pecado das origens não teria sido um ato individual, mas coletivo. $\mathrm{O}$ pecado de Adão teria provocado a queda da humanidade, porque todo ser humano é

mentos da teologia do Antigo Testamento, p. 110-112; BERGANT, D.; KARRIS, R. (Orgs.), Comentário Bíblico, p. 62-63.

${ }^{6}$ KUSS, O., La lettera ai romani, p. 331.

${ }^{7}$ HOFFMANN, P., Morte nella Bibbia, p. 409.

${ }^{8}$ GRELOT, P., Reflexões sobre o problema do pecado original, p. 69. 
visto como um ser adâmico. Adão é concebido como que presente em todo ser humano. Assim, pecando, Adão teria tornado o gênero humano mortal. Depois do pecado de Adão, o ser humano viveria sob o império da morte. Assim como o pecado original é compreendido como uma situação que o ser humano herda, e não um ato voluntário, algo semelhante ocorre com a morte: o ser humano nasce numa condição carnal marcada pela morte. Quando o ser humano nasce já recebe a morte como herança. A existência humana entra no mundo juntamente com a morte. Dizer vida significa dizer uma vida que é mortal. Assim, pela desobediência de Adão, o pecado e a morte teriam passado a reinar no mundo. Em Adão, todos os seres humanos se tornaram herdeiros da culpa original e da morte. Através de Adão, os seres humanos estariam condenados ao pecado e à morte. A negatividade da morte reforçaria a negatividade da culpa. O pecado disseminaria o reinado da morte, que é seu fruto e salário $(\mathrm{Rm} 6,23)$.

$\mathrm{Na}$ visão paulina, a lei antiga estava a serviço da morte (2Cor 3,7). Este poder mortífero da lei seria condicionado pela carne $(\mathrm{Rm} 8,3)$. Seria na carne que se manifestaria a dominação do pecado. O pecado seria a potência de morte que impera na carne. O que a lei não poderia fazer, Deus fez, enviando o seu Filho ao mundo "numa carne semelhante à do pecado e em vista do pecado" ( $\mathrm{Rm} 8$,2). Nascido na linhagem de Adão e se solidarizando com o destino mortal dos seres humanos, Cristo assumiu as consequências do pecado, entre as quais a morte, com toda a sua carga de angústia e seus efeitos devastadores, como causa penal imposta. Cristo experimentou a radicalidade da morte. Provou sua constituição interna. Superou e venceu a negatividade da morte com a sua própria morte. Cristo teria que necessariamente morrer porque assumiu uma condição humana marcada pelo pecado e pela morte. Assumindo uma carne mortal, Cristo teria que necessariamente morrer. Ressuscitando, teria colocado fim ao poder aniquilador e ao império da morte $(2 \mathrm{Tm} 1,10$; 1Cor 15,25-26). Na morte de Cristo, a morte humana foi verdadeiramente redimida.

Cristo teria transformado a morte de uma paixão imposta em uma ação livre e libertadora, superando sua negatividade através da ressurreição. A redenção operada por Cristo não anulou a morte física, mas a superou e a relativizou. ${ }^{9}$ Doravante, a morte teria passado de pena de culpa a ingresso na vida eterna. Cristo iluminou e transformou o sentido espiritual da morte.

\footnotetext{
${ }^{9}$ GNILKA, J., Acerca de la escatología del Nuevo Testamento, p. 763.
} 
Em Cristo, a morte teria se tornado ocasião de páscoa e trânsito. Para aquele que morre com Cristo, a morte foi definitivamente vencida graças ao poder vitalizador do Ressuscitado. Aquele que morre com Cristo, também viverá com ele eternamente. $\mathrm{O}$ batizado é visto como alguém que participa misteriosamente da morte e ressurreição de Cristo ( $\mathrm{Rm}$ 6,2-3). O batismo significaria a passagem da condição adâmica à condição crística. $\mathrm{O}$ batizado é visto como aquele que morre em Adão e ressuscita em Cristo.

Enfim, no âmbito bíblico, a relação entre a morte e o pecado é vislumbrada em alguns textos do AT (Sb 2,23-24; Eclo 25,24) e explicitada no NT, particularmente com Paulo. Na visão bíblica, principalmente do NT, a morte física não seria um elemento constitutivo do ser humano, caso Adão não pecasse. A morte teria passado a ser uma dimensão integrante da existência a partir do pecado de Adão. Com Adão teria começado a disseminação da semente da morte no mundo. O reinado da morte teria entrado no mundo com Adão e saído com Cristo. Assumindo a morte humana como sua, Cristo teria colocado um ponto final no reinado da morte no mundo através da ressurreição.

\section{Desenvolvimento teológico sobre a morte como consequência do pecado original}

A morte como consequência do pecado original é um tema clássico do discurso teológico. Esse tema está presente na teologia patrística, medieval e contemporânea. Historicamente, a teologia interpretou os dados da escritura sobre a relação entre a morte e o pecado de forma fisicista. Assim, o pecado de Adão introduziu, no mundo, a morte em sua dimensão física.

Na patrística, na Primeira Carta de Clemente e na Epistola de Barnabé, dos padres apostólicos, já encontram alusões sobre a entrada da morte no mundo por causa do pecado. Para a Primeira Carta de Clemente, a morte teria entrado no mundo por causa da injusta e da ímpia inveja. A Carta se apoia em Sb 2,24 para explicar a aparição da morte física no meio da humanidade originária com o fratricídio de Caim. Justino, padre apologista, afirma que o gênero humano teria se precipitado, desde Adão, na morte e no erro da serpente, cometendo cada um o mal por sua própria culpa. Adão e a serpente seriam os responsáveis pelo fato do gênero humano se encontrar sob o império da morte e do erro. Taciano, discípulo de Justino, associa a liberdade diante da ação moral e a morte. O ser humano morreria por causa de sua própria culpa em razão do mal cometido. A liberdade, agindo de forma 
moralmente inadequada, teria introduzido a morte no mundo. Segundo Teófilo de Antioquia, padre apologista, pela desobediência de Adão o ser humano teria conhecido o trabalho, as dores e as tristezas e teria se submetido ao poder da morte. ${ }^{10}$

Irineu (130-202), membro da Escola de Antioquia, medita sobre o paralelo entre Adão e Cristo a partir de Rm 5,12-21: "Como pela desobediência de um só homem o pecado entrou no mundo e pelo pecado a morte, assim pela obediência de um só homem foi introduzida a justiça que traz como fruto a vida ao homem morto". ${ }^{11}$ A humanidade teria tropeçado e caído com o primeiro Adão e se levantado e se redimido com o segundo Adão (Cristo). O próprio Adão teria sido reconciliado em Cristo para que exista uma unidade de todo o gênero humano. Em Adão, haveria uma solidariedade e uma unidade no pecado e na morte e, em Cristo, uma solidariedade e uma unidade na justiça e na reconciliação. Adão e Cristo polarizariam a humanidade de dois modos diferentes. Para Irineu, a morte, consequência do pecado original, refere-se à dimensão física, enquanto diluição corpórea, e à dimensão espiritual, como distanciamento de Deus, a segunda morte. ${ }^{12}$

Tertuliano (160-220), membro da Escola de Antioquia, também faz um paralelo entre Adão e Cristo: toda alma, que estaria vinculada a Adão e não a Cristo, seria impura; o não batizado estaria revestido da imagem de Adão, o homem terreno (1Cor 15,45-53), pela ligação com a transgressão e por consórcio com a morte. O pecado e a morte estariam justapostos. ${ }^{13} \mathrm{Na}$ visão de Tertuliano, todo ser humano estaria, de algum modo, relacionado com Adão e, portanto, participaria da transmissão de seu pecado que corrompe a natureza. Participando da condição adâmica, todo ser humano herdaria as consequências dos atos de Adão: o pecado, a morte, o mal, o sofrimento etc. $\mathrm{O}$ ser humano nasceria com um registro adâmico, porém seria revestido de um novo registro em Cristo. Por isso, o ser humano se mortificaria em Adão e vivificaria em Cristo. ${ }^{14}$

Tratando do sentido do batismo das crianças, Cipriano de Cartago (séc. III) afirma que o recém-nascido não tem nenhum pecado ao nascer

\footnotetext{
${ }^{10}$ RUIZ DE LA PEÑA, J. L., El don de Dios, p. 111-112; LADARIA, L. F., Teología del pecado original y de la gracia, p. 79-80.

${ }^{11}$ IRINEU DE LIÃO, Contra as heresias, 1. III, 21,10.

${ }^{12}$ IRINEU DE LIÃO, Contra as heresias, 1. III, 18,7.

${ }^{13}$ LADARIA, L. F., Teología del pecado original y de la gracia, p. 82.

${ }^{14}$ RUIZ DE LA PEÑA, J. L., El don de Dios, p. 117.
} 
carnalmente segundo Adão, salvaguardando a contaminação com a morte que ele contrai em seu nascimento. ${ }^{15}$ Herdando o pecado de Adão, as crianças herdariam também a morte, logo necessitariam serem batizadas e redimidas em Cristo. $\mathrm{O}$ batismo das crianças se justificaria em razão dos pecados alheios, herdados de Adão, e não cometidos livremente, como no caso dos adultos. Os pecados herdados, contraídos com o nascimento, seriam mais graves do que os pecados pessoais dos adultos. O batismo purifica dos pecados herdados e não os cometidos pessoalmente. ${ }^{16}$

Segundo Ambrósio de Milão (340-397), fundamentado em Rm 5,12, todos nós teríamos pecado no primeiro homem e, pelo suceder-se da natureza, teria um suceder-se da culpa desde um até todos. Adão estaria em cada um de nós. Em Adão, a condição humana teria se tornado delinquente porque o pecado teria passado através de um para todos. Adão pereceu e, nele e com ele, todos nós perecemos. Assim, ninguém estaria isento do pecado de Adão, nem sequer a criança que tenha vivido um só dia. Todos necessitariam do batismo e da redenção de Cristo. ${ }^{17}$

Os padres capadócios (Basílio de Cesareia, Gregório de Nissa, Gregório Nizianzeno), Atanásio e João Crisóstomo evitam o uso do termo grego hamartia para designar a situação pecaminosa na qual nós teríamos nascido, mas reservam-no para os pecados pessoais. No entanto, defendem a inclusão de todos em Adão, apelando com frequência para a tipologia Adão-Cristo, e descrevem a condição na qual nasceriam todos os seres humanos em termos de morte e enfermidade. Trata-se de uma condição enferma que necessitaria de uma ação vivificadora e restauradora. ${ }^{18}$

Na visão de Pelágio (350-423), monge irlandês, não haveria uma relação direta entre a morte, o pecado de Adão e o pecado que afeta o gênero humano. Segundo Pelágio, comentando o texto de Rm 5,12, a morte e o pecado teriam entrado no mundo através de Adão. Tanto a morte em sua dimensão física quanto em sua dimensão moral, que seria o pecado. A concepção paulina sobre a universalidade do pecado e da morte não excluiria os justos que não pecariam. Pelágio concentra seu interesse nos pecados pessoais que afetariam a maior parte das pessoas. Trata-se de uma universalidade moral que teria permitido ao apóstolo Paulo elaborar suas formulações gerais sobre a universalidade

\footnotetext{
${ }^{15}$ RUIZ DE LA PEÑA, J. L., El don de Dios, p. 118.

${ }^{16}$ LADARIA, L. F., Teología del pecado original y de la gracia, p. 83.

${ }^{17}$ RUIZ DE LA PEÑA, J. L., El don de Dios, p. 119-120.

${ }^{18}$ RUIZ DE LA PEÑA, J. L., El don de Dios, p. 120-121.
} 
do pecado. Porém, na visão de Pelágio, não haveria um nexo direto entre o pecado de Adão, os pecados pessoais e a morte dos seres humanos. Para Pelágio, o pecado de Adão seria pessoal e não uma ação que teria contaminado a humanidade. O ser humano não herdaria o pecado de Adão. O ser humano não nasceria pecador, mas se tornaria pelo uso de sua liberdade. O pecado de Adão seria um mau exemplo. Para Pelágio, toda vez que o ser humano peca ele imita o mau exemplo de Adão. Pela bondade inata na criação e na natureza, pelo uso da liberdade e pela capacidade de fazer o bem, o ser humano poderia viver sem pecar. Assim, o ser humano poderia alcançar a salvação, que seria fruto de uma conquista pessoal, caso ele não pecasse. Para Pelágio, o pecado original não seria uma herança, mas um mau exemplo deixado por Adão. $O$ batismo de uma criança, que não tem pecado pessoal, seria um ato de consagração. $\mathrm{O}$ batismo purificaria dos pecados pessoais e não de pecados alheios. ${ }^{19}$

Os discípulos de Pelágio, os pelagianos, desenvolveram uma postura mais radical. Segundo Mário Mercator, Adão foi feito mortal, de modo que pecasse ou não iria morrer. Para o pelagiano Celéstio, Adão morreria independentemente do pecado, porque a morte é um fato natural que pertence à existência humana. ${ }^{20}$

Em controvérsia com Pelágio, Agostinho (354-430) afirma que o pecado de Adão teria afetado a todos, formando uma massa de condenados. Em Adão, todos nós tínhamos pecado e morreríamos. Em Adão, os seres humanos formariam uma unidade, logo nele e com ele todos tinham pecado. O pecado de Adão teria tornado todos os seres humanos pecadores. Nascemos num estado de culpa e estaríamos condenados a morrer. O pecado original seria transmitido ao gênero humano pela geração física e não pela imitação, como sustenta Pelágio. O pecado original teria afetado a liberdade humana de modo que o ser humano não seria capaz de nenhum ato bom, sem o auxílio da graça. O ser humano não seria capaz de viver sem pecar, pois sua liberdade estaria escravizada pelo pecado desde as origens. O pecado pessoal do ser humano seria uma forma de reforçar o pecado original presente na humanidade. A salvação se daria pelos méritos de Cristo e não pelos méritos do ser humano, como sustenta Pelágio. Agostinho defende a universalidade do pecado para afirmar a universalidade da salvação em Cristo. A teologia do pecado original estaria em função da soteriologia. As crianças também precisariam ser salvas,

${ }^{19}$ LADARIA, L. F., Teología del pecado original y de la gracia, p. 86-87.

${ }^{20}$ RUIZ DE LA PEÑA, J. L., El hombre y su muerte, p. 14. 
pois nasceriam marcadas por uma situação de pecado. Assim, o batismo de uma criança seria necessário para purificar do pecado original e para a sua salvação. ${ }^{21}$

Segundo Agostinho, o dom da imortalidade paradisíaca significaria um poder não morrer. Para Agostinho, Adão teria sido criado mortal e imortal: "mortal porque poderia morrer, imortal porque poderia não morrer". ${ }^{22} \mathrm{O}$ motivo da morte seria o pecado. A imortalidade seria um privilégio originário, não de sua constituição natural, mas da providência de Deus, presente na árvore da vida, que remediaria exteriormente a proclividade da natureza humana para a morte. ${ }^{23} \mathrm{~A}$ imortalidade não seria uma propriedade da natureza, mas um dom concedido a Adão, externamente por Deus.

No período medieval (séc. V-XV), a relação entre a morte e o pecado original foi determinada pela influência de Agostinho. Não se registram notáveis mudanças de perspectivas. O texto bíblico decisivo, que trata do binômio morte-pecado, continua sendo Rm 5,12-21. A morte, pena de pecado, continua sendo, principalmente, morte física. O pecado original, transmitido pela geração física, passa a ser visto como privação da justiça original.

$\mathrm{Na}$ visão de Boaventura (1221-1274), a imortalidade das origens procederia de um dom divino inerente à alma, cuja vontade estaria sujeita ao corpo de tal modo que, enquanto a vontade não fosse desviada pelo pecado, o corpo, ainda que conservando sua possibilidade de desagregação, não se corromperia. Adão teria perdido o dom da imortalidade, proporcionando a entrada da morte no mundo, mediante a corrupção da vontade através do pecado. A morte provocaria uma desconstrução da unidade ontológica do ser humano, proporcionando uma diluição do corpo. A parte mortal do composto humano seria o corpo. Diferente de Agostinho, Boaventura defende uma interiorização da imortalidade de Adão. ${ }^{24}$

Seguindo esta linha da interiorização da imortalidade defendida por Boaventura, Tomás de Aquino (1225-1274) argumenta que o corpo do homem inocente era indissolúvel, não por natureza, mas por uma força sobrenatural concedida por Deus e presente na alma, mediante a qual aquela poderia preservá-lo da corrupção. ${ }^{25} \mathrm{~A}$ morte representaria a separação, a corrupção

${ }^{21}$ LADARIA, L. F., Teología del pecado original y de la gracia, p. 88-91.

${ }^{22}$ AGOSTINHO, La Genesi, 1. VI, c. 25, n. 36.

${ }^{23}$ AGOSTINHO, La Genesi, 1. VI, c. 25, n. 36.

${ }^{24}$ RUIZ DE LA PEÑA, J. L., El hombre y su muerte, p. 15-16.

${ }^{25}$ ST I, q. 97. 
e a dissolução da unidade corpo-alma. Assim, a imortalidade consistiria na manutenção da integridade ontológica do ser humano. A rebelião do apetite carnal, a morte e todos os males corporais seriam penas do pecado dos primeiros pais. A morte seria natural pelo estado da matéria e castigo pela perda do favor divino. Por causa do pecado dos primeiros pais, toda a natureza humana teria passado aos seus descendentes a sujeição à morte. ${ }^{26}$ Apoiando-se em Rm 5,12, Tomás de Aquino afirma que Adão teria introduzido no mundo os defeitos corporais (a morte, a fome, a sede e outros) que seriam penas de pecado. ${ }^{27}$

João Duns Escoto (1266-1308), aproximando-se de Agostinho e afastando-se de Boaventura e Tomás, afirma que Adão poderia morrer e não morrer; o morrer estaria relacionado com a natureza do corpo e não morrer seria um dom da graça, plasmado na árvore da vida. A imortalidade teria um caráter extrínseco. A possibilidade de não morrer não deve ser entendida como uma isenção absoluta da morte natural. Adão, em sua inocência original, experimentaria uma paulatina deteriorização biológica e um desgaste corporal irreversível. Chegando ao estado limite do desgaste de sua condição física, Adão seria transladado por Deus ao status termini da existência, com o qual se evitaria a morte. Porém, se Deus não fizesse isso, Adão morreria e sua morte não seria pena de pecado (que, por hipótese, não ocorreria), mas condição ou paixão em consequência de sua natureza. Ou seja, em razão da progressiva debilidade de sua condição física, ainda que Adão não pecasse, sua existência chegaria a um limite e teria um fim. A vida de Adão chegaria a uma conclusão e a um termo devido ao avanço do desgaste de sua condição física. No entanto, essa conclusão da vida de Adão não significaria a morte enquanto corrupção e dissolução, mas como termo existencial. ${ }^{28}$

Os reformadores protestantes (Lutero, Calvino e Melanchton), influenciados por Agostinho, compreendem o pecado original, que teria introduzido a morte no mundo, em termos existenciais. Para Lutero, o pecado teria corrompido o ser humano na sua totalidade, tornando-o absolutamente necessitado da graça e da salvação de Cristo. O pecado seria a força que opõe o ser humano a Deus e o faria rejeitá-lo. O pecado original, resultado da culpa pessoal de Adão, seria o pecado por antonomásia que comportaria na perda de todas as forças e faculdades do ser humano. A culpa de Adão teria se convertido

\footnotetext{
${ }^{26}$ ST II, II, q. 164.

${ }^{27}$ ST III, q. 14.

${ }^{28}$ RUIZ DE LA PEÑA, J. L., El hombre y su muerte, p. 16-17.
} 
na culpa de cada ser humano através da experiência da concupiscência, que consiste na inclinação para o pecado, o mal e a impossibilidade de se fazer o bem. Lutero identifica a concupiscência com o pecado original, responsável pela corrupção da natureza. $O$ pecado original seria a autoafirmação do ser humano, prescindindo de seu fundamento e de sua referência a Deus. O ser humano corrompido pelo pecado teria a concupiscência entranhada nele. Seguindo a linha de Lutero, Melanchton concebe o pecado original como uma ruptura na comunhão com Deus. Para Melanchton, o pecado original estaria relacionado com a concupiscência (tradição agostiniana) e com a privação da justiça original (tradição anselmiana). Para Calvino, a corrupção da natureza seria algo natural, no sentido de que nasceria com ela. A morte seria a consumação da condição pecaminosa na qual o ser humano estaria imerso. A ruptura na comunhão com Deus já seria uma situação de morte na qual o pecador se encontraria mergulhado. A morte representaria o desfecho de uma vida pautada pelo pecado. ${ }^{29}$

$\mathrm{Na}$ contemporaneidade, alguns teólogos reafirmam a visão clássica do nexo causal entre a morte e o pecado sem oferecer uma reinterpretação ou uma problematização. Em sintonia com o apóstolo Paulo e a tradição cristã, eles concebem a morte como uma sequela natural do pecado. ${ }^{30}$ Já, outros teólogos apresentam algumas dificuldades frente à associação entre a morte e o pecado. Estes teólogos fazem uma distinção entre a morte como fenômeno natural (dimensão biológica) e a morte como juízo (dimensão teológica). Para a primeira distinção, a morte é um fenômeno latente à condição finita da existência que não tem nenhuma relação com o pecado. A morte é um elemento constitutivo da finitude da vida humana, animal e vegetal. Essa condição finita não pode ser caracterizada como pecado. Para a segunda distinção, há uma relação intrínseca e etiológica entre a morte e o pecado. O pecado é a ruptura na comunhão com Deus que por sua vez leva à morte. Aqui, a morte possui uma dimensão qualitativa, referindo-se não a qualquer ser vivente ou organismo, mas especificamente ao ser humano. Trata-se de uma compreensão propriamente humana e pessoal da morte. Estas distinções trazem em seu bojo concepções diferentes da origem da vida. A concepção de que a morte é um

${ }^{29}$ LADARIA, L. F., Teología del pecado original y de la gracia, p. 95-97.

${ }^{30}$ MERSCH, É., La théologie du corps mystique, p. 321; SCHMAUS, M., Dogmatica Cattolica, p. 357-359; VOLK, H., Morte nella teologia, p. 418-419; CULLMANN, O., Immortalità dell'anima o risurrezione dei morti?, p. 29-39; SAYÉS, J. A., Antropología del hombre caido, p. 26-28. 359-361; POZO, C.,Teología del más allá, p. 466-468. 
fenômeno natural compreende a vida em termos biológicos e físicos. A vida é caracterizada pelo organismo em funcionamento, com seus órgãos, células e membros. A morte significa a imobilidade, o não funcionamento e a dissolução do organismo. Trata-se do fim natural de um organismo que completou o seu ciclo de existência. A morte afeta igualmente o ser humano, o animal e o vegetal. Neste horizonte, a vida e a morte são vistas em termos físicos. A concepção segundo a qual a morte é sequela natural do pecado entende a vida como dom de Deus. A vida é concebida no horizonte da relação entre o ser humano e Deus. A vida tem sua origem em Deus. Ela depende da ação de um ser transcendente e divino. O pecado é a negação ou o afastamento da fonte da vida, gerando a morte. A separação de Deus tem como fruto a morte. Neste sentido, a morte tem uma dimensão espiritual sendo vista como manifestação do juízo e da ira de Deus. Aqui, a vida e a morte são vistas em termos transcendentes e espirituais. ${ }^{31}$ Clodovis Boff distingue três dimensões sobre a morte: a dimensão biológica (comum a todo ser vivente), a dimensão antropológica (especificamente do ser humano) e dimensão teológica (própria da relação entre o ser humano e Deus). ${ }^{32}$

É possível perceber a partir de um olhar histórico que a teologia fez uma associação entre o pecado e a morte. Fundamentando-se em Rm 5,12, a teologia clássica concebeu a morte física como uma consumação do pecado original. $\mathrm{O}$ surgimento da morte física estaria vinculado à culpa original. A teologia contemporânea problematizou essa associação distinguindo algumas dimensões da morte: como um fenômeno natural que afeta todo ser vivente (dimensão biológica), como um evento especificamente humano (dimensão antropológica) e como fruto da transgressão na comunhão com Deus (dimensão teológica). A teologia contemporânea rompeu com o fisicismo na compreensão da morte, percebendo-a partir de outros olhares.

\section{As declarações do magistério sobre a morte como consequência do pecado original}

A primeira declaração do magistério sobre a relação morte-pecado é

${ }^{31}$ BRUNNER, E., L'eternità come futuro e tempo presente, p. 145-150; PANNENBERG, W., Antropologia en perspectiva teologica, p. 173-177; RAHNER, K., Sulla teologia della morte, p. 33-36; THIELICKE, H., Vivir con la muerte, p. 54-93; KEHL, M., Escatología, p. 251-263; MOLTMANN, J., La venida de Dios, p. 115-135; RATZINGER, J., Escatología, p. 111-120.

${ }^{32}$ BOFF, C., Escatologia, p. 42-56. 
feita pelo sínodo de Cartago (418), cujo primeiro cânon afirma: "Quem disser que Adão, o primeiro homem, foi criado mortal, de modo que, pecasse ou não pecasse, teria corporalmente morrido, isto é, teria deixado o corpo não por causa do pecado, mas por necessidade natural, seja anátema". ${ }^{33}$ Esta declaração consiste numa recusa à tese dos pelagianos e uma confirmação da posição de Agostinho. Para os pelagianos, a morte é um evento natural e constitutivo da existência humana, independentemente do pecado original. Assim, Adão, figura representativa do gênero humano, morreria ainda que não pecasse. A declaração acolhe a posição de Agostinho para quem a entrada da morte no mundo seria em razão da culpa. Deste modo, a morte corporal não seria uma necessidade da natureza, mas mérito do pecado. Para a declaração, a consequência do pecado original seria a morte física, enquanto dissolução biológica e separação de corpo e alma. No segundo cânon, Cartago defende a prática do batismo de crianças, cuja finalidade seria a remissão dos pecados, "para que pela regeneração venha a ser purificado nelas o que contraíram quando foram geradas". 34

A segunda declaração do magistério é feita pelo sínodo de Orange (529). O primeiro cânon, apoiado em Agostinho, afirma que o homem todo, em corpo e alma, "foi mudado para pior" em consequência do pecado original. A prevaricação de Adão teria atingido o corpo, sujeitando-o à corrupção, e a alma, danificada no exercício de sua liberdade. ${ }^{35}$ No horizonte de Orange, a natureza humana não seria maléfica em si mesma, mas teria sido deteriorada pela prevaricação de Adão. $\mathrm{O}$ pecado original não teria atingido apenas uma dimensão do homem (corpo ou alma), mas sua totalidade ontológica (corpo e alma). O segundo cânon de Orange declara que "se alguém afirma que a prevaricação de Adão prejudicou somente a ele e não também à sua descendência, ou que decerto passou a todo gênero humano só a morte do corpo, que é o castigo do pecado, não porém o pecado que é a morte da alma, atribui a Deus uma injustiça". ${ }^{36}$ Para a declaração, o pecado de Adão não teria sido simplesmente um ato individual de modo que tivesse efeito somente sobre ele, mas se trataria de um ato coletivo cujas repercussões afetaram o gênero humano. $\mathrm{O}$ pecado das origens teria atingido tanto Adão quanto a sua descendência. A prevaricação de Adão teria semeado a morte do corpo, que

\footnotetext{
${ }^{33} \mathrm{DH} 222$.

${ }^{34} \mathrm{DH} 223$.

${ }^{35} \mathrm{DH} 371$.

${ }^{36} \mathrm{DH} 372$.
} 
seria a pena do pecado, e a morte da alma, que seria o próprio pecado. Em outros termos, o pecado original teria disseminado a morte física e espiritual.

A terceira declaração é feita pelo Concílio de Trento, no Decreto sobre o pecado original (1546). O primeiro cânon afirma que Adão, transgredindo a ordem de Deus no paraíso, "perdeu imediatamente a santidade e a justiça" e entrou num "estado de prevaricação", incorrendo "na ira e na indignação de Deus e, por isso, na morte com que Deus havia ameaçado anteriormente e, com a morte" submetendo-se ao domínio do diabo. Em sintonia com Orange, o concílio afirma que o pecado de Adão teria proporcionado uma decaída do homem todo, em corpo e alma. ${ }^{37}$ A visão do pecado original como perda da justiça original já tinha sido defendida por alguns teólogos medievais, dentre os quais Anselmo, Boaventura e Tomás de Aquino. A perda da justiça original, ou seja, do dom da imortalidade física, concedido por Deus, significaria a entrada da morte no mundo. A morte teria sido o resultado de uma punição de Deus, provocado em sua ira, imposta sobre Adão, que teria violado o estado de santidade original através do pecado. Com a entrada do pecado e da morte no mundo, o diabo começaria o seu reinado.

O segundo cânon do Decreto sobre o pecado original afirma que o pecado de Adão teria prejudicado ele próprio e todo o gênero humano. O pecado consistiria na perda da justiça e da santidade concedidas por Deus. Fundamentado em Rm 5,12, o Decreto afirma que Adão teria transmitido a todo o gênero humano não só a morte e as penas do corpo, mas também "o pecado que é a morte da alma". 38 Esse segundo cânon de Trento consiste, basicamente, numa reafirmação do que já tinha sido declarado pelo segundo cânon de Orange: a transmissão e os efeitos do pecado de Adão. O terceiro cânon, em sintonia com Agostinho, trata da necessidade absoluta de Cristo, único mediador e reconciliador entre Deus e os homens, para a salvação e a remissão do pecado original, transmitido por propagação e não por imitação, como afirmavam os pelagianos. O quarto cânon trata, principalmente, do fundamento e da justificação da prática eclesial do batismo de crianças. As crianças, também, nasceriam com o pecado original, que herdariam de Adão, e por isso deveriam ser batizadas para a remissão dos pecados e a salvação. O quinto cânon trata da graça de Jesus Cristo, conferida pelo batismo, que eliminaria o pecado original, mas não apagaria a concuspiscência. Essa declaração do Decreto é uma rejeição da visão de Lutero que identificava

\footnotetext{
${ }^{37}$ DH 1511.
}

${ }^{38} \mathrm{DH} 1512$. 
o pecado original com a concupiscência. Alguns teólogos medievais também defendiam essa identificação. ${ }^{39}$ As declarações anteriores ao Vaticano II se ocuparam mais das consequências do que com a definição do próprio pecado original.

O Concílio Vaticano II (1962-1965), define em que consiste o pecado original, seus efeitos e sua relação com a morte. Segundo a Gaudim et Spes (GS) n. 13, o ser humano, criado por Deus num estado de justiça, teria sido seduzido pelo diabo, usando de forma abusiva sua liberdade, rebelandose contra Deus e buscando sua realização fora dele. Em virtude do pecado das origens, o ser humano não reconheceria a Deus como seu fundamento, nem como seu fim último e, em consequência disso, teria comprometido sua relação consigo, os outros e as demais criaturas. O efeito do pecado teria sido a divisão que recairia sobre o próprio ser humano e a coletividade. ${ }^{40}$

A GS 18 afirma que:

a fé cristã ensina que a própria morte corporal, de que o homem seria isento se não tivesse pecado, acabará por ser vencida, quando o homem for pelo onipotente e misericordioso Salvador restituído à salvação, que por própria culpa perdera. Com efeito, Deus chamou e chama o homem a unir-se a ele, com todo o seu ser, na perpétua comunhão da incorruptível vida divina. Esta vitória, alcançou-a o Cristo ressuscitado, libertando com a própria morte o homem da morte. ${ }^{41}$

Esta afirmação está em sintonia com Cartago, tratando somente da morte corporal, que seria pena de pecado, e não da morte da alma (morte espiritual), que seria o próprio pecado, conforme defendeu Orange e Trento. A afirmação, também, está em continuidade com Trento e a teologia medieval quando afirma que se Adão não pecasse seria imortal fisicamente. A novidade introduzida pela GS 18, em relação aos documentos magisteriais anteriores, se refere à dimensão salvífica da morte. Cristo, assumindo a morte como sua, libertaria o ser humano do domínio onipresente da morte. A morte não poderia ser redimida por um ato ou por um decreto extrínseco, mas pelo fato de Cristo assumi-la interiormente e fazê-la como própria. Cristo assumiu e experimentou a morte em sua interioridade, tornando-se seu autêntico redentor.

\footnotetext{
${ }^{39}$ DH 1513-1515.

${ }^{40} \mathrm{DH} 4313$.

${ }^{41}$ DH 4318.
} 
Em suma, as declarações oscilaram ora retomando Cartago, ora Orange. A prevaricação de Adão teria semeado o pecado (morte da alma, morte espiritual) e a pena do pecado (morte corporal, morte física). A imortalidade, como dom divino, seria uma privação da morte física e da morte espiritual. Preponderantemente, tanto a imortalidade quanto a morte são vistas numa perspectiva física.

\section{Para uma reinterpretação da morte como consequência do pecado original}

A visão clássica da morte como consequência do pecado original e da imortalidade paradisíaca (dom preternatural) está imbuída de um caráter fisicista. É necessário reinterpretar a índole penal da morte, as noções do pecado original e da imortalidade paradisíaca dentro de um horizonte mais existencial, evolutivo e contemporâneo, no sentido teológico.

Uma visão evolutiva do mundo resiste em aceitar que a natureza humana tenha sido "mudada como consequência de um fato pertencente à ordem moral, como seria o primeiro pecado". ${ }^{42}$ Como o pecado das origens, um fato de ordem moral e espiritual, foi capaz de produzir um impacto antropológico a ponto de mudar radicalmente a constituição da existência humana, passando-a de imortal à mortal? Como um fato extrínseco pode ter sido tão determinante a ponto de mudar a constituição interna da existência humana? A morte é um evento biológico necessário para o processo evolutivo. A curva do processo evolutivo da existência biológica de todo ser vivente tem um limite espaçotemporal. O processo evolutivo se dá pela superação de etapas, pela quebra de paradigmas e pelo surgimento de novos ciclos. O progresso da vida biológica requer a destruição dos viventes. O ser humano precisa morrer para que a espécie subsista e se renove. É inerente a toda existência biológica a ideia de um fim e de um prazo de validade. ${ }^{43}$ Neste contexto, seria impensável levantar a hipótese de um ser humano, como no caso de Adão, que fosse privado do evento da morte. Ele seria um ser biologicamente inconcebível, visto como mitológico. A suposta imortalidade do ser humano paradisíaco o coloca em um estado vital “absolutamente inviável e que longe de ser um privilégio para o homem, antes

${ }^{42}$ RUIZ DE LA PEÑA, J. L., El hombre y su muerte, p. 352.

${ }^{43}$ TROISFONTAINES, R., Je ne meurs pas..., p. 72-73; SMULDERS, P., La visión de Teilhard de Chardin, p. 196-200; SCHOONENBERG, P., L'homme et le péché, p. 244; GRELOT, P., Réflexions sur le problème du péché originel, p. 475. 
seria uma anomalia incompatível com sua natureza de homem". 44 "A ideia de que a 'queda' alterou fisicamente a estrutura celular ou psicológica do homem (e da natureza?) não é só absurda quanto não tem fundamento bíblico". ${ }^{45}$ Pensar num ser finito e contingente que não passasse pela experiência do fim de sua existência seria uma possibilidade bizarra. É inerente ao ser finito a ideia de que sua existência experimentará uma conclusão.

$\mathrm{Na}$ visão clássica, a relação morte-pecado foi marcada por uma compreensão fisicista. Na reflexão bíblico-teológica contemporânea, a ideia da morte não se restringe a um significado meramente físico-biológico, mas possui, também, um sentido espiritual (separação da comunhão com Deus) e escatológico (condenação eterna). Na visão bíblica, vida e morte não são consideradas realidades puramente físicas, mas devem ser compreendidas no horizonte da relação com Deus. ${ }^{46}$ Assim, a morte não pode ser concebida como um simples término da vida física, mas enquanto ausência de uma comunhão pessoal com Deus. A morte, como pena de pecado, não seria em sua dimensão física, mas espiritual, enquanto separação da relação com Deus. Neste contexto, a morte adquire uma conotação predominantemente espiritual.

A morte, pena de pecado, se refere, simplesmente, ao seu aspecto físico ou existe uma alternativa válida a esta interpretação? Uma alternativa plausível, adotada por muitos teólogos, se refere a uma interpretação mais existencial e menos física da morte e do morrer. Neste cenário, a morte é compreendida como pena de pecado por causa de seu aspecto angustiante, doloroso, brutal, hostil e negativo. A morte pena de pecado é aquela que reina no mundo de nossa experiência, de nosso sofrimento, de nossa solidão, de nossa existência vazia e de nosso pressentimento diante dela. A novidade desta interpretação está no nível do significado antropológico-existencial, na forma de se experimentar a morte e o morrer. Esta interpretação não está no plano da causalidade da morte, mas no sentido pessoal e existencial. ${ }^{47}$

\footnotetext{
${ }^{44}$ LAVOCAT, A. R., Réflexions d'un paléontologiste sur l'etat originel de l'humanité et le péché originel, p. 594.

${ }^{45}$ TILLICH, P., Teologia Sistemática, p. 296.

${ }^{46}$ SEIBEL, W., Lo stato originale dell'uomo, p. 579-580; DUBARLE, A. M., La maladie et la mort d'après l'Ancien Testament, p. 131-132; RUIZ DE LA PEÑA, J. L., El don de Dios, p. 167; LADARIA, L. F., Teología del pecado original y de la gracia, p. 45.

${ }^{47}$ SMULDERS, P., La visión de Teilhard de Chardin, p. 198-199; SCHOONENBERG, P., L'homme et le péché, p. 244; MARTELET, G., Libre réponse à un scandale, p. 33-34; RUIZ DE LA PEÑA, J. L., El don de Dios, p. 166; NOCKE, F. J., Escatologia, p. 139; GRESHAKE, G., Vita, p. 80 .
} 
A ênfase no aspecto físico, na visão da morte como pena de pecado, por parte da tradição cristã, pode ser compreendida por uma escassa atenção dada à índole genuína do morrer humano. $\mathrm{O}$ acento na dimensão antropológicoexistencial da morte foi dado pela filosofia da existência do século XX, principalmente com M. Scheler, M. Heidegger e J. P. Sartre. ${ }^{48}$ A morte é uma possibilidade constituinte do existir humano. É a última possibilidade da finitude humana. O ser humano está ordenado para essa possibilidade desde o seu nascimento. O acento antropológico da abordagem filosófica influenciou a teologia do século $\mathrm{XX}$, proporcionando uma humanização da morte. ${ }^{49}$ No âmbito teológico, a morte não tem somente uma dimensão físicobiológica, mas também pessoal e existencial, enquanto realidade inerente e iminente do existir humano. A morte não é só um evento passivo, que o ser humano sofre como fruto de uma imposição da natureza, mas também é ação, um acontecimento pessoal, uma realidade que ele assume como sua. A morte não pode ser vista simplesmente como uma fatalidade da natureza, nem como um evento impessoal e nem como uma paixão inerente à condição humana, mas também como evento pessoal, singular e intransferível..$^{50}$ Assim, é possível superar o formalismo, o objetivismo, o fisicismo e o jurisdicismo da relação morte-pecado e situá-la num horizonte personalista e existencial. Neste contexto de uma reinterpretação da dimensão penal da morte, ainda que Adão não pecasse, não significa que estaria isento de um fim físico e viveria eternamente, mas sua existência teria uma conclusão como transformação e consumação na graça divina. ${ }^{51}$ Uma consequência de uma visão simplesmente física do caráter penal da morte é uma infravalorização do corpo e uma supervalorização do espírito.

A visão fisicista da morte como pena de pecado está conectada a uma visão moralista do pecado original e a uma percepção fisicista de sua transmissão. Historicamente, a transmissão do pecado original foi concebida em termos de

\footnotetext{
${ }^{48}$ SCHUMACHER, B., Confrontos com a morte, p. 54.

${ }^{49}$ OLIVEIRA, R. A., A morte como tema antropológico e teológico, p. 11-25.

${ }^{50}$ MERSCH, É., La théologie du corps mystique, p. 313; TROISFONTAINES, R., Je ne meurs pas..., p. 153-164; GEFFRÉ, C., La mort comme nécessité et comme liberté, p. 269-270; RAHNER, K.; Sulla teologia della morte, p. 30; BORDONI, M., Dimensioni antropologiche della morte, p. 73; RUIZ DE LA PEÑA, J. L., La otra dimension, p. 314.

${ }^{51}$ TROISFONTAINES, R., Je ne meurs pas..., p. 155-157; SCHMAUS, M. Dogmatica Cattolica, p. 358; RAHNER, K., Sulla teologia della morte, p. 33; FLICK, M.; ALSZEGHY, Z., Il peccato originale in prospettiva evoluzionistica, p. 216; BOROS, L., Mysterium Mortis, p. 175-177; RUIZ DE LA PEÑA, J. L., El don de Dios, p. 166-167.
} 
geração e propagação, no sentido físico e biológico. Os pais transmitiriam aos filhos o pecado original. Uma geração transmitiria para a outra geração o mal herdado. É preciso reinterpretar e superar essa visão fisicista da transmissão do pecado em função de uma percepção mais social e existencial. Neste sentido, o pecado original, na interpretação de P. Schoonenberg, deve ser pensado em termos de uma solidariedade no pecado. Os condicionamentos sociais, culturais e biológicos, que são prévios ao exercício da liberdade do ser humano, determinam as suas escolhas. $\mathrm{O}$ ser humano se encontra num mundo marcado por uma situação de pecado que o envolve e influencia as decisões de sua liberdade. O ser humano, desde o seu nascimento, encontra-se imerso numa história de pecado alheio, da qual não consegue se distanciar, e que determina suas ações. Neste sentido, o pecado original se refere à condição de ser-situado na qual o ser humano se encontra e que possui uma dimensão subjetiva, como um momento interior determinante, e uma objetiva, como situação externa que o influencia. Trata-se de um estado, de um modo de existir, que precede o surgimento de uma ação pessoal e que envolve as decisões pessoais. A condição de ser-situado afeta todos os seres humanos. Assim, o pecado do mundo se identifica com o pecado original próprio de cada ser humano. O ser humano se torna solidário e assume a culpa alheia como sua. ${ }^{52}$ Seguindo uma linha reflexiva semelhante a de Schoonenberg, K. Rahner compreende o pecado original como "a universalidade e a insuperabilidade da determinação pela culpa da situação da liberdade na única história humana". ${ }^{53}$ O contexto social no qual o ser humano encontra-se inserido é o lugar em que a liberdade toma suas decisões. O ser humano exerce sua liberdade subjetiva inserido numa situação marcada por objetivações de culpa. Essa determinação, enquanto situação de culpa alheia, é originária, permanente, universal e inevitável. A liberdade humana está determinada pela culpa desde a origem da história. ${ }^{54}$

O ser humano nasce em um mundo condicionado pelo pecado e seus efeitos. Há uma história de pecado que antecede a existência do ser humano.

\footnotetext{
${ }^{52}$ SCHOONENBERG, P., L'uomo nel peccato, p. 701-715.

${ }^{53}$ RAHNER, K., Curso fundamental da fé, p. 138.

${ }^{54}$ RAHNER, K., Curso fundamental da fé, p. 133-144. Há outras reinterpretações do pecado original na atualidade: a concepção existencial da teologia protestante, a visão evolutiva de T. de Chardin, a ótica psicanalítica de E. Drewermann, a explicação a partir das estruturas de pecado da teologia da libertação e a leitura de J. Alison que concebe a graça como ausência de violência proporcionada pelo pecado original (ANDRADE, B., Pecado original o gracia del perdón?, p. 162-178).
} 
Trata-se de um pecado estruturado no mundo e na existência humana. Deste modo, o ser humano quando nasce se torna solidário com todos os pecadores marcados pela história do pecado. Transportando essa solidariedade no pecado para a compreensão da morte, é possível afirmar que a morte é um evento pessoal e social. Ninguém morre e nem vive sozinho. O morrer humano é co-morrer, visto que ele morre em sintonia com todos os mortais. $\mathrm{O}$ que se percebe é o lado pessoal e individual da morte, no entanto ela é um momento coletivo e solidário. $\mathrm{O}$ ser humano padece a morte que os demais humanos padecerão. O lado solidário está oculto na visível dimensão individual da morte. No âmbito cristão, cada ser humano quando morre experimenta a sua morte, mas em comunhão com Cristo e com os outros. ${ }^{55}$

Por fim, é preciso afirmar que, independentemente do pecado original, a vida tem um caráter mortal. No coração da vida está a morte. No nascimento, a morte já está presente e atuante no existir humano. A morte é uma realidade onipresente em todo o campo da existência humana desde a sua concepção. A vida e a morte entraram juntas no cenário do mundo. A condição mortal da existência humana é anterior ao pecado. "A morte começou a existir no momento em que a vida começou a existir. Aceitar a vida significa, por isso, aceitar que ela seja intrinsecamente mortal, não por causa de Adão e de seu pecado". ${ }^{56}$

\section{Conclusão}

1) Historicamente, as noções de pecado original, de morte e de imortalidade paradisíaca estão marcadas por um caráter fisicista e biologicista. Estas noções foram concebidas por uma interpretação unilateral. No entanto, é preciso reinterpretar essas noções numa perspectiva mais existencial e social, superando uma abordagem materialista.

2) A morte e a vida estão reciprocamente implicadas. Ambas começaram a existir simultaneamente. A morte é uma realidade presente e atuante no coração da existência desde sua concepção. Dizer vida é dizer vida mortal, independentemente do pecado original. A morte significa que a vida tem um limite e um confim. A vida é circunscrita pela morte. A morte pertence à constituição finita da existência. O pecado é uma situação posterior à morte.

55 BRUNNER, E., L'eternità come futuro e tempo presente, p. 206-207; BORDONI, M.; CIOLA, N., Gesù nostra speranza, p. 207-213.

${ }^{56}$ MANCUSO, V., L'anima e il suo destino, p. 192. 
3) Uma interpretação possível que procura salvaguardar a validade bíblico-teológica da tese da morte como consequência do pecado original é afirmar que seu caráter penal está na forma de experimentar a morte enquanto um evento que contém uma unidade dialética: passivo e ativo, biológico e existencial, brutal e pessoal, fato imposto e assumido.

4) Dizer que a morte entrou no mundo por causa de um fato de ordem moral e espiritual, como o pecado original, soa como uma afirmação bizarra. É impossível pensar que a constituição da existência humana foi mudada pelo pecado original. Também, é igualmente bizarro e inimaginável pensar num ser humano que não faça a experiência da morte, devido a uma suposta ausência do pecado original.

5) O pecado original deve ser pensado numa perspectiva mais existencial e solidária e menos fisicista e biologicista. Neste sentido, o pecado original poderia ser pensado na perspectiva de uma solidariedade com os pecadores. $\mathrm{O}$ ser humano nasce num contexto mundano marcado por estruturas e por uma história de pecado. Ele se torna solidário com todos os pecadores. Uma visão mais solidária e existencial do pecado original conduz a uma visão mais solidária e existencial da morte.

\section{Referências bibliográficas}

AGOSTINHO. La Genesi: La genesi alla lettera, Roma: Città Nouva, 1989. (NBA IX/2).

ANDRADE, B. Pecado original o gracia del perdón? Salamanca: Secretariado Trinitario, 2004.

BERGANT, D.; KARRIS, R. (Orgs.). Comentário Bíblico. São Paulo: Loyola, 1999.v.1.

BOFF,C. Escatologia. Breve tratado teológico-pastoral. São Paulo: Ave Maria, 2012.

BORDONI, M. Dimensioni antropologiche della morte. Roma: Herder, 1969. BORDONI, M.; CIOLA, N. Gesù nostra speranza. Bologna: Dehoniane, 2000. BOROS, L. Mysterium Mortis. L'uomo nella decisione ultima. Brescia: Queriniana, 1979.

BRUNNER, E. L'eternità come futuro e tempo presente. Bologna: Dehoniane, 1973. 
CIMOSA, M. Morte-risurrezione nella Bibbia. Roma: Borla, 2006. (Dizionario di Spiritualità Biblico-Patrística, 44).

CULLMANN, O. Immortalità dell'anima o risurrezione dei morti? Brescia: Paideia, 1986.

DENZINGER, H. Compêndio dos símbolos, definições e declarações de fé e moral. Traduzido com base na $40^{\mathrm{a}}$ edição alemã (2005), aos cuidados de Peter Hünermann. São Paulo: Paulinas / Loyola, 2007.

DUBARLE, A. M. La maladie et la mort d'après l'Ancien Testament. In: TRIACCA, A. M. La maladie et la mort di chrétien dans la liturgie. Conférences Saint-Serge XXIe Semaine d'études liturgiques, Paris 1-4 juillet 1974. Roma: Liturgiche, 1975. p.127-139.

FLICK, M.; ALSZEGHY, Z. Il peccato originale in prospettiva evoluzionistica. Gregorianum, v.47, p. 201-225, 1966.

GEFFRÉ, C. La mort comme nécessité et comme liberté.Vie Spirituelle, v.108, n.492, p. 264-280, mar.1963.

GEFFRÉ, C. Morte: Teologia bíblica e sistemática. In: LACOSTE, J. Y. (Dir.). Dicionário Crítico de Teologia. São Paulo: Paulinas / Loyola, 2004. p. 1195-1199.

GNILKA, J. Acerca de la escatología del Nuevo Testamento. Scripta Theologica, v.33, n.3, p. 753-772, 2001.

GRELOT, P. Réflexions sur le problème du péché originel. Nouvelle Revue Théologique, v.89, n.5, p. 449-484, 1967.

GRELOT, P. Reflexões sobre o problema do pecado original. São Paulo: Paulinas, 1969.

GRESHAKE, G. Vita - più forte della morte. Brescia: Queriniana, 2009.

HOFFMANN, P. Morte nella Bibbia. In: FRIES, H. (Ed.). Dizionario Teologico. Brescia: Queriniana, 1967. p. 402-413. v. 2.

IRINEU DE LIÃO. Contra as heresias. São Paulo: Paulus, 1995. (Coleção Patrística, 4).

LADARIA, L. F. Teología del pecado original y de la gracia. Madrid: BAC, 2004.

LAVOCAT, A. R. Réflexions d'un paléontologiste sur l'etat originel de l'humanité et le péché originel. Nouvelle Revue Théologique. v.89, n.5, p. 582-600, 1967. 
KEHL, M. Escatología. Salamaca: Sigueme, 2003.

KUSS, O. La lettera ai romani. Brescia: Morcelliana, 1962.

MACKENZIE, J. L. Morte. In: MACKENZIE, J. L. Dicionário Bíblico. São Paulo: Paulinas, 1984. p. 632-634.

MANCUSO, V. L'anima e il suo destino. Milano: Cortina, 2007.

MARTELET, G. Libre réponse à un scandale. La faute originelle, la souffrance et la mort. Paris: Cerf, 1986.

MERSCH, É. La théologie du corps mystique. Paris: Desclée de Brouwer, 1946. MOLTMANN, J. La venida de Dios. Salamanca: Sigueme, 2004.

NOCKE, F. J. Escatologia. Brescia: Queriniana, 2006.

OLIVEIRA, R. A. A morte como tema antropológico e teológico. Revista Eclesiática Brasileira, v.73, n. 289, p. 5-37, jan. / mar. 2013.

PANNENBERG, W. Antropologia en perspectiva teologica. Salamanca: Sigueme, 1993.

POZO, C.Teología del más allá. Madrid: BAC, 2008.

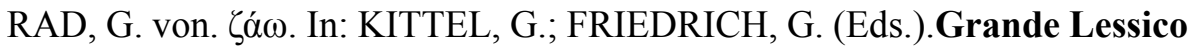
del Nuovo Testamento, Brescia, 1967. p. 1394-1410. v. III.

RAHNER, K. Sulla teologia della morte. Brescia: Morcelliana, 1965.

RAHNER, K. Curso fundamental da fé. São Paulo: Paulus, 1989.

RATZINGER, J. Escatología. Barcelona: Herder, 2008.

RUIZ DE LA PEÑA, J. L. El don de Dios. Santander: Sal Terrae, 1991.

RUIZ DE LA PEÑA, J. L. EI hombre y su muerte. Burgos: Aldecoa, 1971.

RUIZ DE LA PEÑA, J. L. La otra dimensión. Madrid: Eapsa,1975.

SAYÉS, J. A. Antropología del hombre caido. El pecado original. Madrid: BAC, 1991.

SCHMAUS, M. Dogmatica Cattolica.Torino: Marietti, 1964. v. IV / 2.

SCHOONENBERG, P. L’homme et le péché. Tours: Mame, 1967.

SCHOONENBERG, P. L'uomo nel peccato. In: FEINER, J.; LÖHRER, M. (Dir.). Mysterium Salutis. Brescia: Queriniana, 1970. p. 589-719.v. IV.

SCHUMACHER, B. Confrontos com a morte. A filosofia contemporânea e a questão da morte. São Paulo: Loyola, 2009. 
SEIBEL, W. Lo stato originale dell'uomo. In: FEINER, J.; LÖHRER, M. (Dir.). Mysterium Salutis. Brescia: Queriniana, 1970. p. 555-588. v. IV.

SMULDERS, P. La visión de Teilhard de Chardin. Paris: Desclée de Brouwer, 1965.

THIELICKE, H. Vivir con la muerte. Barcelona: Herder, 1984.

TILLICH, P. Teologia Sistemática. São Paulo: Paulinas; São Leopoldo: Sinodal,1987.

TOMAS DE AQUINO. Suma Teológica: parte I, questões 44-119. São Paulo: Loyola, 2003. v. 2

TOMAS DE AQUINO. Suma Teológica: II seção da II parte, questões 123189. São Paulo: Loyola, 2005. v. 7.

TOMAS DE AQUINO. Suma Teológica: parte III, questões 1-59. São Paulo: Loyola, 2002. v. 8.

TROISFONTAINES, R. Je ne meurs pas... Paris: Editions Universitaires, 1960.

VOLK, H. Morte nella teologia. In: FRIES, H. (Ed.). Dizionario Teologico. Brescia: Queriniana, 1967. p. 414-425. v. II.

WESTERMANN, C. Fundamentos da teologia do Antigo Testamento. Santo André: Academia cristã, 2011.

WOLFF, H. W. Antropologia do Antigo Testamento. São Paulo: Loyola, 1975.

Renato Alves de Oliveira

Doutor em Teologia Sistemática pela Pontifícia Universidade Gregoriana (Roma) Docente de Teologia Sistemática na Pontifícia Universidade Católica de Minas Gerais Belo Horizonte / MG - Brasil E-mail: praobh@yahoo.com.br

Recebido em: 20/09/17 Aprovado em: 09/03/18 